\title{
THE COLLEGE SELECTION BASED ON THE EDUCATION COST, UNIVERSITY IMAGE AND LECTURER QUALITY
}

\author{
LA SELECCIÓN DE LA UNIVERSIDAD BASADA EN EL COSTO DE LA \\ EDUCACIÓN, LA IMAGEN DE LA UNIVERSIDAD Y LA CALIDAD DEL PROFESOR
}

Dedy Ansari Harahap ${ }^{1 *}$; L Lasmanah ${ }^{1}$; Nunung Nurhayati ${ }^{2}$; Sri Suwarsi ${ }^{1}$; Pupung Purnamasari ${ }^{2}$; Dita Amanah ${ }^{3}$.

1. Department of Management, Faculty of Economics and Business. Universitas Islam Bandung, Indonesia.

2. Department of Accounting, Faculty of Economics and Business. Universitas Islam Bandung, Indonesia.

3. Department of Business of Education, Faculty of Economics and Business Education. Universitas Pendidikan Indonesia, Bandung, Indonesia.

*Corresponding author: Dedy Ansari Harahap, correo electrónico: dedyansarihrp@gmail.com

\begin{abstract}
The purpose of this paper is to analyze the effect of education cost, university image and quality of lecturers on student decisions to choose a college. To achieve the proposed goals, a model is applied that reflects the effect of education costs, university image and quality of lecturers on student decisions to choose universities. This model was tested through the use of multiple linear regression equations and the sample was 388 student candidates. The conceptual model shows that the image of a university is the most influential construct on student decisions to choose a campus, followed by the quality of lecturers and the cost of education. In this paper, the cost of education variable produces a reliability of 0.861 , a college image of 0.918 and a lecturer quality of 0.937 . Further research is needed in order to find more reliable measurements of indicators of education cost, university image and quality of lecturers. The image of a university is the highest impression that is in the minds of students in choosing a university, followed by the quality of lecturers and the cost of education. Proven. The results show that the image of the university, the quality of the lecturers and the cost of education have an influence on student decisions to choose a campus.
\end{abstract}

Keywords: education costs; university image; lecturer quality; student decisions; choosing a college; Indonesia.

Cómo citar:

Harahap, D.A., Lasmanah, L., Nurhayati, N., Suwarsi, S., Purnamasari, P., \& Amanah, D., (2021). THE COLLEGE SELECTION BASED ON THE EDUCATION COST, UNIVERSITY IMAGE AND LECTURER QUALITY. Revista de Investigaciones Universidad del Quindio, 33(2), 32-44. https://doi.org/10.33975/riuq.vol33n2.600

Información del artículo: Recibido: 23 junio 2021; Aceptado: 19 agosto 2021

Revista de Investigaciones Universidad del Quindío,

33(2), 32-44; 2021.

ISSN: 1794-631X e-ISSN: 2500-5782

Esta obra está bajo una licencia Creative Commons Atribución-

NoComercial-SinDerivadas 4.0 Internacional. 


\section{RESUMEN}

El propósito de este trabajo es analizar el efecto del costo de la educación, la imagen universitaria y la calidad de los profesores en las decisiones de los estudiantes para elegir una universidad. Para lograr los objetivos propuestos se aplica un modelo que refleja el efecto de los costos educativos, la imagen universitaria y la calidad de los docentes en las decisiones de los estudiantes para elegir universidades. Este modelo fue probado mediante el uso de ecuaciones de regresión lineal múltiple y la muestra fue de 388 estudiantes candidatos. El modelo conceptual muestra que la imagen de una universidad es el constructo que más influye en las decisiones de los estudiantes para elegir un campus, seguido de la calidad de los profesores y el costo de la educación. En este artículo, la variable costo de la educación produce una confiabilidad de 0.861 , una imagen de collage de 0.918 y una calidad de conferenciante de 0.937 . Se necesitan más investigaciones para encontrar medidas más fiables de los indicadores del coste de la educación, la imagen universitaria y la calidad de los profesores. La imagen de una universidad es la impresión más alta que tienen los estudiantes al elegir una universidad, seguida de la calidad de los profesores y el costo de la educación. Probado. Los resultados muestran que la imagen de la universidad, la calidad de los profesores y el costo de la educación influyen en las decisiones de los estudiantes para elegir un campus.

Palabras clave: costos de educación; imagen universitaria; calidad del profesor; decisiones de los estudiantes; elección de universidad; Indonesia.

\section{INTRODUCTION}

The trend in the development of private universities in Indonesia is quite high, as seen by the increasing number of people who wish to pursue higher education, thus providing opportunities for private universities to continue to improve quality. Private Higher Education Institutions (PHEIs) are mostly focused on income derived from tuition fees, of course different from Public Higher Education Institutions (PUHEs). Therefore, the community continuously compares the quality of education between the two sectors of higher education providers (Kee \& Sia, 2013). Marketing in the higher education (HE) sector is not new. Research has shown that to maintain the sustainability of campus activities, HE must use a marketing framework and meet the needs of their customers by adding value to the university's sustainable competitive advantage (Hoyt \& Brown, 2003; Kotler \& Fox, 1995).
Higher Education Management needs to market their institutions to build uniqueness, highlight strengths and provide strong reasons for prospective students to choose the institution. Therefore, many researchers have demonstrated that marketing plays an important role in student enrollment, and these researchers have tried to exemplify how students choose HE (Tapp, Hicks, \& Stone, 2004; Cubillo, Sanchez, \& Cervin, 2006). But this is not an easy matter for every university to develop higher education institutions in Indonesia, given the tighter competition with other universities (Harahap, Hurriyati, Gaffar, \& Amanah, 2018). Studies that have been documented in some literature that focus on higher education (HE), there are many factors that influence students' decisions to choose a particular college, namely the cost of education (Xiaoping, 2002), and perceptions about the quality of educational programs (Zain \& Nik-Yacob, 1995). 
Institutional characteristics include image, geographic location, academic programs and facilities, social life and social facilities, accommodation and dining facilities, safety, lighting and security, sports facilities (Absher \& Crawford, 1996; Tackey \& Aston, 1999), and the possibility for students to live close to home or family (Jackson, 1982). Ford et al., (1999), stated that students are attracted to institutional factors such as degree program flexibility, academic reputation and prestige that reflect national and international recognition, physical aspects of the campus such as the quality of infrastructure and services, and the time required for program completion. In addition to these characteristics, Maringe (2006), found that the availability of equipment, for example computers, the quality of library facilities, the quality of lecturers, research reputation, cleanliness, part-time work opportunities, employee attitudes, availability of telephones and quiet areas for learning and opportunities for graduates to get jobs influence the choice of college.

From the literature review on previous tertiary institutions, there are many factors and studies that examine students' decision to continue their studies at university. However, there are still few studies investigating the effect of education costs, university image and lecturer quality on university selection. These factors are important to research because in Indonesia these three factors are very influential for society, students and parents in choosing certain universities as places to continue their studies. Circumstances or conditions that are not in accordance with what the community expects, will raise doubts which can result in the decision not to choose the university, in this case the decision not to continue the study in the desired place, so research is needed to see the effect on the choice of university. This research involves 3 (three) factors that influence the decision of students to choose a university to continue their studies, namely the cost of education, the image of the university and the quality of the lecturers.

\section{LITERATURE REVIEW}

The cost of education is often matched by spending on education. Education costs in this scope have a broad definition, namely all types of expenditures relating to the provision of education, both in the form of money and goods and labor, which are expressed in monetary units (Supriyadi, 2010). The concept of education costs can be distinguished by classifying the costs that occur, namely social and private costs, opportunity costs and money costs, and explicit and implicit costs (Latchanna \& Hussein, 2007). According to Lupiyoadi \& Hamdani (2006), higher education institutions use different tuition fee determinations for each student and program, including: 1). Based on the study program; example: economics, engineering, language, law, 2). Based on student level; example: undergraduate students are different from postgraduate, where the cost of postgraduate is more expensive, 3). Based on student credit load, 4). Based on the type of student program; example: programs with a degree (S1) or nondegree / graduate / diploma, and 5). Based on the time and place of lecture; example: evening classes are different in cost from regular classes during the day. According to Kotler \& Armstrong (2016), there are four indicators that characterize prices, namely: price affordability, price compatibility with product quality, price competitiveness and price compatibility with benefits.

Several studies have been conducted regarding the effect of costs in making institutional choices (Domino, Libraire, Lutwiller, Superczynski, \& Tian, 2006; Wagner \& Fard, 2009; Webb, 1993). It was found that the costs associated with learning at an institution were the most important factor (Domino, Libraire, Lutwiller, Superczynski, \& Tian, 2006; Wagner \& Fard, 2009), while others found that costs were the fourth most influential factor in the choice of educational institutions.

In this study the authors perceive price as the cost of education as measured by using four 
measurement indicators as follows, namely: 1) Affordability of tuition fees, 2) Compatibility of tuition fees with study programs, 3) Competitive tuition fees, and 4) Suitability of tuition fees with benefits. The cost of education is an important reason for prospective students to make the decision to choose to continue their studies in higher education. Thus, the first hypothesis is established: Hypotheses \# 1 (H1): cost of education will significantly influence a student's decision to choose a college.

According to Kotler \& Armstrong (2016), image is a set of beliefs, ideas and impressions that a person has about an object. So, people's attitudes and actions towards certain objects are largely determined by the object's image. This image is obtained by the college through a series of accumulated abilities and experiences so that the college has the best performance for stake holders. The university image can be defined as the sum of all beliefs that individuals have towards the university (Arpan, Raney, \& Zivnuska, 2003; Helgesen \& Erik Nesset (2007), show that student satisfaction has a positive impact on student perceptions of university image. From some of the theoretical explanations above, the writer can conclude that the definition of the image of a university is an assessment given by the community or prospective students to the university, or the perception of all activities carried out by the university.

According to Hoeffler \& Keller (2003), indicators of image are: professional impression, modern impression, serving all segments and attention to consumers. The indicators used to measure the image of the university according to Helgesen \& Erik Nesset (2007), are: recognition of campus qualifications, career and job potential, student perceptions of campus and perceptions of college service users on campus. In this study, the image of the university is measured using the following four measurement indicators, namely: 1) Good name, namely the impression the university has, 2) Career and job potential, 3) Serving all segments, the products produced by the university are able to reach various groups of people, and 4) Attention to consumers, universities are able to prove concern for their students. To investigate the image of the university towards student decisions, this study proposes a second hypothesis as follows: Hypotheses \# 2 (H2): university image will significantly influence students' decision to choose a college.

Lecturers are professional educators and scientists with the main task of transforming, developing and disseminating science, technology and art through education, research and community service (Indonesia, 2005). According to Narimawati (2005), the main key to improving the quality of higher education is that institutions or leaders must improve the quality of lecturers, which will result in increasing motivation and job satisfaction and further commitment to the organization or institution. Many institutions have or are developing competency requirements for lecturers. However, in most cases, this requirement is only for a group of lecturers and not the entire higher education industry (Hellison, 2003). According to Evertson, Hawley, \& Zlotnik (1985), the existence of a system-wide consensus stating the minimum requirements and competence of lecturers makes it difficult to maintain and guarantee quality education. Lecturers who are well equipped with relevant knowledge in their field, this specialization determines the quality of teaching.

Teaching experience, on average, is positively related to student achievement throughout the lecturer's career (Kini \& Podolsky, 2016). Measuring the quality of teaching becomes very complex because it involves teaching preparation and self-confidence (Darling-hammond, Holtzman, Gatlin, \& Heilig, 2005), experience and knowledge (Goe, 2007; Schmidt \& Hunter, 1983), pedagogical skills, positive attitudes and classroom management skills so that they can be organized (Hamid, Hassan, \& Ismail, 2012). Baird (1967), concluded that good teaching, high academic standards and special programs are what students are looking for. 
Indicators of the quality of lecturers (Indonesia, 2005), are: 1) Lecturers have many qualifications of S2 / S3, 2) Lecturers have expertise in their respective fields, 3) Lecturers are broad-minded according to scientific disciplines, and 4) Lecturers have prepared learning materials with ripe. To investigate and see to what extent the influence of lecturer quality on student decisions, this study proposes the following hypothesis: Hypotheses \# 3 (H3): lecturers quality will significantly influence students' decisions to choose a college.

According to Kotler \& Armstrong (2016), decision making is an individual activity that is directly involved in obtaining and using the goods offered, including the decision-making process in the preparation and determination of these activities (Swastha \& Handoko, 2008). Consumer behavior will determine the decisionmaking process in purchasing and before deciding to purchase goods or services, consumers usually go through various stages Kotler \& Armstrong (2016). The definition of a purchasing decision above is assumed to be a student's decision to choose a university.

In their study of the decision of prospective students to choose a university, Agrey \& Lampadan (2014), found factors that influence the decision-making process, namely: 1) a support system that includes physical (bookstores and counseling offices) and non-physical (scholarship availability, value transfer, etc.), 2) learning environment related to the existence of modern learning facilities, institutional reputation, libraries, laboratory computers, affordable tuition fees, etc., 3) prospects for graduates to be accepted into work after graduation, 4) strong student programs such as health care , housing, accommodation and extra-curricular activities, 5) a safe and friendly environment associated with a safe campus and supportive campus employees. The factors above are also highlighted in the research of (Çokgezen, 2014; Ciriaci \& Muscio, 2011).
The indicators in this study were adapted from the research of (Harahap, Hurriyati, Gaffar, Wibowo, \& Amanah, 2017b), namely the student's decision to choose a university is measured using the following five measurement indicators, namely: 1) Introduction to universities, 2) Search for university information, 3) Evaluation the alternative to choosing a university, 4) the decision to choose a university, and 5) behavior after choosing a university. From several previous studies in Indonesia, research has never been conducted on the effect of education costs, university image and quality of lecturers simultaneously on student decisions to choose to study. The author seeks to explore the reciprocal effects of student decisions in choosing universities and proposes a third hypothesis: Hypotheses \# 4 (H4): cost of education, university image and lecturers quality will significantly influence the student's decision to choose a college.

\section{RESEARCH METHODS}

\section{- Methodology}

This study employed a quantitative approach to investigate the effect of cost, university image, and lecturer quality on students' decision in attending a university. Data were collected from a private university in Bandung, West Java Province, Indonesia. The university is one of the biggest private universities in the province, with total of 13,750 graduate and postgraduate students. In addition, this research university holds an A accreditation from the national board of higher education in Indonesia, offers a wideranging study programs, and having research partnerships with many public and private parties and both national and international institutions.

\section{- Sample definition}

This study was limited to one private university in West Java due to limited access to gather data from private universities in the province. The target population of the study was graduate 
students in the selected university. There were 12,474 graduate students attending study programs in ten faculties. Four hundred graduate students studying in different programs were randomly selected as the participants. They were given access to online survey and asked to complete it, and only 388 responses were finally collected.

\section{- Data collection}

Data were collected using a questionnaire measuring students' perceptions when selecting the university. The questionnaire had been refined in the pre-testing and pilot testing stage administered to first-to four-year students. Due to the Covid-19 outbreak limiting the access to face-to-face and paper-based survey administration, the final questionnaire was made in an online form using Google form. The link was sent to students' email and the duration of survey completion was three months from April to June 2020.

There were two parts of the questionnaire. The first part asked individual background, including gender, ethnicity, and faculty they attended to. There were six options of ethnicities: Sundanese, Bataknese, Javanese, Minangese, Betawi, and others; ten options of faculties: Syaria Da'wah, Tarbiya, Law, Psychology, Economics and Business, Communication, Technical Studies, Mathematics and Science, and Medical Studies. The second part of the questionnaire included items measuring education cost, university image, quality of lecturer, and students' decision to study. The measure related to education cost were developed based on Kotler \& Armstrong (2016), consisting of six items (i.e., 'Education cost in this university is affordable'). Meanwhile, there were 12 items measuring the construct of university image and developed based on Helgesen \& Erik Nesset (2007) (i.e., 'This university has a good image on the community'). The quality of lecturer construct was measured by ten items developed from (Indonesia, 2005) (i.e., The lecturers in this university are knowledgeable and high quality'), and the decision of selecting the study program was developed from (Harahap et al., 2017b), consisting of ten items (i.e., 'I study in this university because it offers a program that fulfils my needs.'). Those items were measured using a 5-point Likert scale where 5 'Strongly Agree' and 1 'Strongly Disagree'.

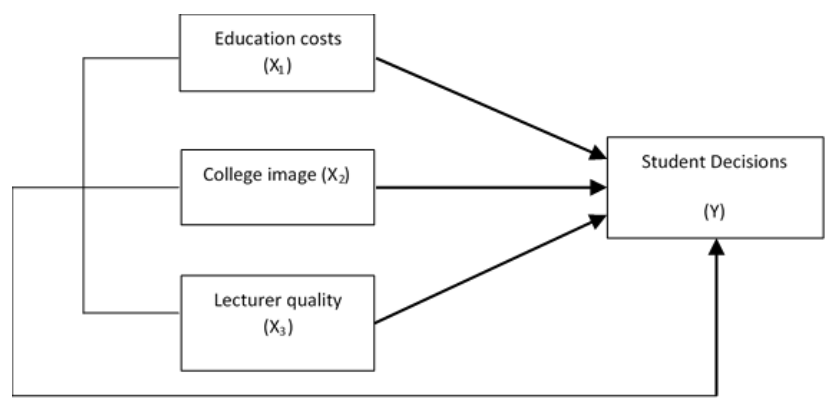

Figure 1. Conceptual model

\section{- Data Analysis}

Data analysis consisted descriptive statistics to describe the data collected without making a generalization of the data. Multiple regression analysis was performed to examine the association and the effect of education cost, university image, and lecturer quality on student choice in studying at the university. A statistical software, IBM SPSS Statistics 26 software, was used to analyze the data.

\section{RESULTS AND DISCUSSION}

\section{Results}

Reliability test was conducted to measure the consistency and stability of each questionnaire item (Sekaran \& Bougie, 2013). This is to ensure that the questionnaire items are error free and produce consistent results. Table 1 shows that the cost of education has an alpha value of 0.811 with 6 items being observed. The university image has an alpha value of 0.948 with 12 observed items, the quality of lecturers has an alpha value of 0.926 with 10 items being observed and student decisions have an alpha value of 0.865 with 10 items being observed. Sekaran \& Bougie (2013), suggest that Cronbach's Alpha is less than 0.6, 
the questionnaire or data items are said to be bad and vice versa. Therefore, the data collected was considered usable for further analysis.

Table 1.Reliability Test Result

\begin{tabular}{lcc}
\hline \multicolumn{1}{c}{ Variables } & $\begin{array}{c}\text { No. of } \\
\text { Item }\end{array}$ & $\begin{array}{c}\text { Cronbach's } \\
\text { Alpha }\end{array}$ \\
\hline Education costs & 6 & .811 \\
\hline College image & 12 & .948 \\
\hline Lecturer quality & 10 & .926 \\
\hline Student decisions & 10 & .865 \\
\hline
\end{tabular}

The detailed demographic attributes of the respondents are shown in Table 2 . The majority of respondents were female $(61.9 \%)$, students were spread across the following faculties $(\mathrm{n}=$ 388). The faculty that has the most students is the Faculty of Economics and Business (21.1\%), and the least is the Faculty of Da'wah (2.1\%). The majority of students come from West Java province $(77.58 \%)$, and the rest $(22.42 \%)$ come from various regions spread across Indonesia and several islands in Indonesia and other countries such as Java and its surroundings, Jakarta, Sumatra, Kalimantan, Sulawesi, Maluku, Nusa Tenggara, Thailand and England.

Table 2.Respondent Characteristic

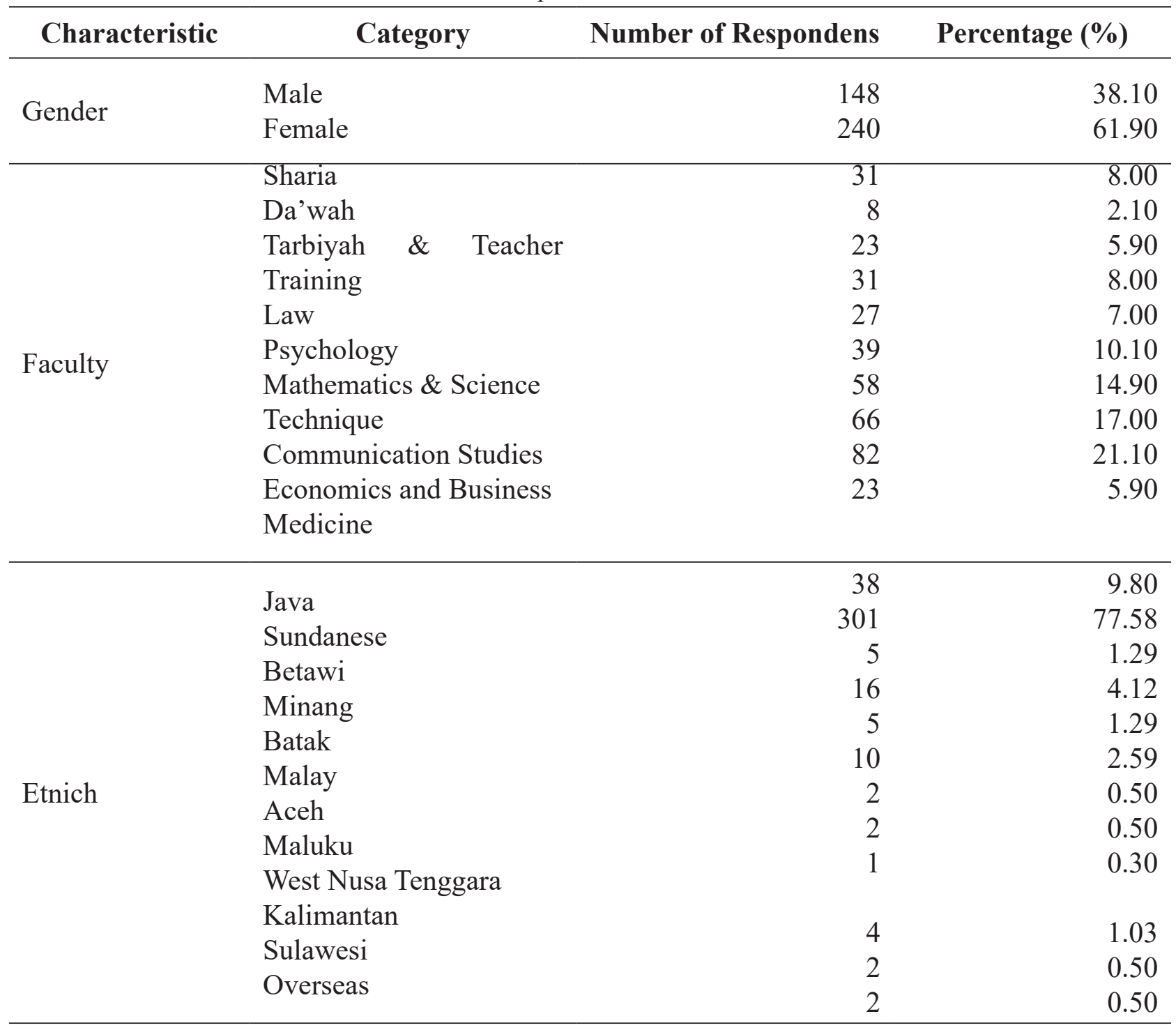


The research data shows the value of the coefficient (b) of each variable consisting of the student's decision to choose to study (Y), the cost of education $\left(\mathrm{X}_{1}\right)$, the image of the university $\left(\mathrm{X}_{2}\right)$ and the quality of the lecturers $\left(\mathrm{X}_{3}\right)$ with a constant $(\alpha)$ of -0.056 , then we get a multiple linear regression model, namely, $\mathrm{Y}=-0.056+$ $0.130 \mathrm{X}_{1}+0.562 \mathrm{X}_{2}+0.259 \mathrm{X}_{3}+\mathrm{e}$, which can be seen in Table 3.

Table 3.Regression Coefficient

\begin{tabular}{lcccc}
\hline \multicolumn{1}{c}{ Variables } & B & S.E & T & Sig. \\
\hline (Constant) & -.056 & .136 & -.411 & .681 \\
Education Cost & .130 & .037 & 3.536 & .000 \\
University Image & .562 & .050 & 11.240 & .000 \\
Lecturer Quality & .259 & .048 & 5.434 & .000 \\
\hline
\end{tabular}

The results of the partial test analysis on the variable cost of education $\left(X_{1}\right)$, obtained the t-count value of 3.536, greater than the t-table value of 1.961. So Hol is rejected and Ha1 is accepted, it means that the cost of education has a significant effect on the student's decision to choose a university. The t-count value of the university image variable $\left(\mathrm{X}_{2}\right)$ is 11.240 (greater than the t-table value of 1.961 ), so Ho2 is rejected and $\mathrm{Ha} 2$ is accepted. This means that the image of the university has a significant effect on student decisions to choose a university. Whereas in the lecturer quality variable $\left(\mathrm{X}_{3}\right)$, the t-count value is 5.434 , greater than the t-table value of 1.961 , so $\mathrm{Ho} 3$ is rejected and $\mathrm{Ha} 3$ is accepted, meaning that the quality of the lecturer has a significant effect on the student's decision to choose a university. All results are shown in Table 3 .

Table 4. The Test F Result

\begin{tabular}{lccccc}
\hline Model & $\begin{array}{c}\text { Sum of } \\
\text { Squares }\end{array}$ & Df & $\begin{array}{c}\text { Mean } \\
\text { Square }\end{array}$ & F & Sig. \\
\hline Regression & 118.090 & 3 & 39.363 & 226.461 & $.000 \mathrm{~b}$ \\
Residual & 66.747 & 384 & .174 & \\
Total & 184.637 & 387 & & \\
\hline
\end{tabular}


the study program offered were the three most important factors influencing students to choose a university.

\section{The Effect of University Image on Decision to Choose a College}

Table 3 shows that the image of the university has a positive relationship and affects students' decisions to choose a university. The coefficient of 0.562 indicates that a $100 \%$ change in the university's image will cause the level of student decisions to choose a university to increase by $56.2 \%$. This means that the image of a university that is owned by a university has a positive or negative impact on everyone, both for society in general and for prospective students in particular. The attractiveness and interest of prospective students can be seen from how good the image of the university is, so that prospective students do not hesitate and even create pride in the college they are going to enter to continue their studies to a higher level at a well-known university. In research (Harahap, Amanah, Gunarto, Purwanto, \& Umam, 2020), stated that the importance of the image of the university for students in choosing studies in college. Research by Khan, Mridha, \& Barua (2009), found that the image of a university is the second highest important factor after teaching quality. In line with research (Hoyt, Jeff E.; Brown, 2003; Wiese, Heerden, Jordaan, \& North, 2009), that the reputation and image of the university is a consideration for students choosing to study in higher education.

\section{The Effect of Lecturer Quality on the Decision to Choose a College}

Table 3 shows that the quality of lecturers has a positive relationship and affects students' decisions to choose universities. The coefficient of 0.259 shows that a $100 \%$ change in the quality of lecturers will cause the level of student decision to choose university to increase by $25.9 \%$. This means that the quality of lecturers who are knowledgeable and highly insightful and have scientific expertise is an important parameter for society, parents and prospective students in deciding the selection of a particular university, because it will be related to the teaching quality of the lecturer and the knowledge expectations that students will get when taking studies. Furthermore, it is hoped that after graduating from the tertiary institution, students will become qualified graduates and can easily get jobs in well-known companies. Metzler \& Woessmann (2010), study found that the quality of lecturers is directly related to student achievement and is very important for lecturers to develop strong teaching competencies to provide quality teaching. One of the competencies they specifically mention in their studies is subject knowledge because without having subject knowledge, lecturers cannot understand students with the relevant knowledge and skills required for a particular subject. Therefore, subject knowledge is basically important for lecturers so that students can meet the desired learning outcomes and are satisfied with their learning (Long, Ibrahim, \& Kowang, 2014).

\section{The Effect of Education Cost, University Image, Lecturer Quality on the Decision to Choose a College}

Table 4 and Table 5 show that the cost of education, the image of the university and the quality of the lecturers together have a positive relationship and influence student decisions to choose a university. The results of the analysis of the value of determination in this study obtained 0.639 , which means that the percentage of tuition fees, image of the university and the quality of the lecturers in explaining the student's decision to choose a university was $63.90 \%$ and the remaining $36.10 \%$ was explained by other variables not examined. This means that the three factors mentioned above are the determining reasons for society, parents and prospective students in deciding to choose to continue their studies at a university. Keling (2006) found that the image and reputation of the university, tuition fees and academic programs have an influence on prospective students in 
deciding to choose a university. Hsieh (2010), also found that the importance of the influence of the quality of lecturers, types and variations of academic programs on students' decisions in choosing universities to continue their studies.

\section{CONCLUSIONS RECOMMENDATIONS}

AND

\section{Conclusions and implications for practice}

This study identifies that the cost of education, image of the university and the quality of lecturers have a statistically significant effect on student decisions to study. Private universities must continue to strive to be more professional in fulfilling the necessary facilities and infrastructure which will have an impact on the tuition fees that will be charged to students, improving the quality and qualifications of their lecturers. The study program that is managed is more creative and prioritizes study programs based on specific skills according to what the job market needs (Harahap, Hurriyati, Gaffar, Wibowo, \& Amanah, 2017a; Harahap et al., 2017b; Harahap et al., 2018; Harahap \& Amanah, 2019).

This study included the cost of education, the image of the university, the quality of the lecturers and the student's decision to continue their studies for analysis. It was found that the education cost construct and the decision to choose a university had a lower level of reliability compared to other constructs (university image, lecturer quality), namely 0.811 and 0.865 , respectively. For this reason, it is hoped that future research can carry out further research to try to find alternative indicators to measure the constructs of prospective student decisions in order to obtain a reliability level above 90 percent in all constructs.
By increasing the interest of prospective students to continue their studies, managers of Islamic private universities must continue to strive to be more professional, improve the quality and qualifications of their lecturers, and determine relatively affordable tuition fees. Management that is more creative and prioritizes study programs based on specific skills according to the needs of the job market. Intense competition in the industrial era 4.0 has experienced almost all sectors including universities, so it is demanded to always build a good image internally and externally related to student perceptions which greatly affect the image and reputation of the university.

\section{Limitations and recommendations for future research}

This study has several limitations. The sample size is relatively small and involves only one private Islamic university in Indonesia. In addition, this study is based on respondents' perceptions and is considered accurate. Based on the determinants identified by students, it is recommended to develop an instrument for measuring the cost of education, the image of the university, the quality of the lecturers and the student's decision to choose to study in higher education and more specific studies in this field are required. Further research could be focused on public universities and other consumer groups, and we recommend considering the factors that influence student decisions to study in higher education at various stages of the student life cycle such as; university accreditation, lecture facilities, study programs, location, promotion, service, safety and comfort that can influence student decisions to study. Thus it makes a good contribution to further research on student decisions to choose to study in higher education. 


\section{REFERENCES}

1. Absher, K., \& Crawford, G. (1996). Marketing the Community College Starts With Understanding Students' Perspectives. Community College Review, 23(4), 59-68. https://doi. org $/ 10.1177 / 009155219602300406$

2. Agrey, L., \& Lampadan, N. (2014). Determinant Factors Contributing to Student Choice in Selecting a University. Journal of Education and Human Development, 3(2), 391-404.

3. Arpan, L. M., Raney, A. A., \& Zivnuska, S. (2003). A cognitive approach to understanding university image. Corporate Communications: An International Journal, 8(2), 97-113. https://doi. org/10.1108/13563280310474535

4. Baird, L. (1967). The educational tools of college bound youth. Iowa.

5. Beneke, J., \& Human, G. (2010). Student recruitment marketing in South Africa - An exploratory study into the adoption of a relationship orientation. African Journal of Business Management, 4(4), 435-447.

6. Ciriaci, D., \& Muscio, A. (2011). University choice, research quality and graduates'employability: Evidence from Italian national survey data.

7. Çokgezen, M. (2014). Determinants of University Choice : A Study on Economics Departments in Turkey. Journal of Higher Education, 4(1), 23-31. https://doi.org/10.2399/yod.14.002

8. Coy-Ogan, L. (2009). Perceived Factors Influencing the Pursuit of Higher Education Among First-Generation College Students. Liberty University.

9. Cubillo, J. M., Sanchez, J., \& Cervin, J. (2006). International students ' decision-making process. International Students, 20(2), 101-115. https://doi.org/10.1108/09513540610646091

10. Darling-hammond, L., Holtzman, D. J., Gatlin, S. J., \& Heilig, J. V. (2005). Does Teacher Preparation Matter? Evidence about Teacher Certification, Teach for America, and Teacher Effectiveness. Education Policy Analysis Archives, 13(42), 1-51. Retrieved from https://eric. ed.gov/?id=EJ846746

11. Domino, S., Libraire, T., Lutwiller, D., Superczynski, S., \& Tian, R. (2006). Higher Education Marketing Concerns: Factors Influence Students' Choice of Colleges. The Business Review Journal, 6(2), 101-111.

12. Evertson, C. M., Hawley, W. D., \& Zlotnik, M. (1985). Making a Difference in Educational Quality Through Teacher Education. Journal of Teacher Education, 36(3), 2-12.

13. Ford, J. B., Joseph, M., \& Joseph, B. (1999). Importance-performance analysis as a strategic tool for service marketers: The case of service quality perceptions of business students in New Zealand and the USA. Journal of Services Marketing, 13(2), 171-186. https://doi. org/10.1108/08876049910266068

14. Goe, L. (2007). The link between teacher quality and student outcomes: A research synthesis. Washington, DC.

15. Hamid, S. R. A., Hassan, S. S. S., \& Ismail, N. A. H. (2012). Teaching Quality and Performance Among Experienced Teachers in Malaysia. Australian Journal of Teacher Education, 37(11), 85103.

16. Harahap, D. A., \& Amanah, D. (2019). Assessment in Choosing Higher Education : A Case of Indonesia. Journal of International Business, Economics and Entrepreneurship, 4(1), 10-21.

17. Harahap, D. A., Amanah, D., Gunarto, M., Purwanto, \& Umam, K. (2020). Pentingnya Citra Universitas Dalam Memilih Studi di Perguruan Tinggi. Niagawan, 9(3), 191-196. https://doi.org/ http://dx.doi.org/10.24114/niaga.v9i3.20819

18. Harahap, D. A., Hurriyati, R., Gaffar, V., \& Amanah, D. (2018). The impact of word of mouth and university reputation on student decision to study at university. Management Science Letters, 8(6), 649-658. https://doi.org/10.5267/j.msl.2018.4.027

19. Harahap, D. A., Hurriyati, R., Gaffar, V., Wibowo, L. A., \& Amanah, D. (2017a). Effect of Word of Mouth on Students Decision to Choose Studies in College. In 1st International Conference on Islamic Economics, Business, and Philanthropy (ICIEBP 2017) (pp. 793-797). Bandung: SCITEPRESS - Science and Technology Publications, Lda.

20. Harahap, D. A., Hurriyati, R., Gaffar, V., Wibowo, L. A., \& Amanah, D. (2017b). Pengaruh Reputasi Universitas Terhadap Keputusan Mahasiswa Memilih Studi di Universitas Islam Sumatera Utara. In Prosiding Seminar Nasional \& Konferensi Forum Manajemen Indonesia (FMI 9), Semarang (pp. 1-12). https://doi.org/10.17605/OSF.IO/8ZG6N 
21. Helgesen, Ø., \& Erik Nesset. (2007). Images, Satisfaction and Antecedents: Drivers of Student Loyalty? A Case Study of a Norwegian University College. Corporate Reputation Review, 10(1), 38-59. https://doi.org/10.1057/palgrave.crr.1550037

22. Hellison, D. (2003). Teaching Responsibility through Physical Activity (Second Edi). Human Kinetics.

23. Hoeffler, S., \& Keller, K. L. (2003). The marketing advantages of strong brands. Brand Management, 10(6), 421-445.

24. Hoyt, Jeff E.; Brown, A. B. (2003). Identifying College Choice Factors to Successfully Market Your Institution. College and University, 78(4), 3-10.

25. Hoyt, J. E., \& Brown, A. B. (2003). Identifying college choice factors to successfully market your institution. College and University, 78(4), 3-10.

26. Hsieh, Y. J. (2010). The decision-making process of international students in Taiwan: A case study. In The Fifth APAIE 2010 Conference, Griffith University, Australia, April 14-16, 2010. Australia.

27. Indonesia, R. UU RI Nomor 14 Tentang Guru dan Dosen Pasal 1 Ayat 2 (2005).

28. Jackson, G. A. (1982). Public Efficiency and Private Choice in Higher Education. Educational Evaluation and Policy Analysis, 4(2), 237-247.

29. Joseph, M., \& Joseph, B. (1998). Identifying needs of potential students in tertiary education for strategy development. Quality Assurance in Education, 6(2), 90-96.

30. Kee, J., \& Sia, M. (2013). University Choice: Implications for Marketing and Positioning. Education, 3(1), 7-14. https://doi.org/10.5923/j.edu.20130301.02

31. Keling, S. B. A. (2006). Institutional factors attracting students to Malaysian institutions of higher learning. International Review of Business Research Papers, 2(1), 46-64.

32. Khan, R. H., Mridha, A. H. A. M., \& Barua, S. (2009). HIGHER EDUCATION IN PRIVATE UNIVERSITIES OF BANGLADESH : A STUDY ON FEMALE STUDENTS ' ENROLLMENT BEHAVIOR. BRAC University Journal, VI(2), 33-48.

33. Kini, T., \& Podolsky, A. (2016). Does Teaching Experience Increase Teacher Effectiveness? A Review of the Research. Washington, D.C. Retrieved from www.learningpolicyinstitute.org

34. Kotler, P., \& Fox, K. (1995). Strategic Marketing for Educational Institutions (2nd ed.). New Jersey: Prentice Hall.

35. Kotler, P. T., \& Armstrong, G. (2016). Principles of Marketing (16th Editi). Pearson.

36. Latchanna, G., \& Hussein, J. . (2007). Economics of Education. New Delhi: Discovery Publishing House.

37. Long, C. S., Ibrahim, Z., \& Kowang, T. O. (2014). An Analysis on the Relationship between Lecturers ' Competencies and Students ' Satisfaction. International Education Studies, 7(1), 37 46. https://doi.org/10.5539/ies.v7n1p37

38. Lupiyoadi, R., \& Hamdani, A. (2006). Manajemen Pemasaran Jasa (Edisi Kedu). Jakarta: Salemba Empat.

39. Maringe, F. (2006). University and course choice Implications for positioning, recruitment and marketing. International Journal of Educational Management, 20(6), 466-479. https://doi. org/10.1108/09513540610683711

40. Metzler, J., \& Woessmann, L. (2010). The Impact of Teacher Subject Knowledge on The Impact of Teacher Subject Knowledge on Student Achievement : Evidence from Within-Teacher WithinStudent Variation. Bonn Germany.

41. Narimawati, U. (2005). Pengaruh Person Jobfit, Kepuasan \& Komitmen Terhadap Keinginan Pindah Dan kinerja Dosen PTS Kopertis Wilayah IV Jabar Dan Banten. Universitas Padjajaran.

42. Schmidt, F. L., \& Hunter, J. E. (1983). Individual Differences in Productivity : An Empirical Test of Estimates Derived From Studies of Selection Procedure Utility. Journal of Applied Psychology, $68(3), 407-414$.

43. Sekaran, U., \& Bougie, R. (2013). Research Methods for Business : A Skill-Building Approach (6th Editio). United Kingdom: John Wiley \& Son Ltd.

44. Supriyadi, D. (2010). Satuan Biaya Pendidikan Dasar dan Menengah. Rujukan bagi Penetapan Kebijakan Pembiayaan Pendidikan Pada Era Otonomi dan Manajemen Berbasis Sekolah. Bandung: PT Remaja Rosdakarya.

45. Swastha, B., \& Handoko, T. H. (2008). Manajemen Pemasaran, Analisa Perilaku Konsumen (Edisi I). Yogyakarta: BPFE.

46. Tackey, N. ., \& Aston, J. (1999). Making the Right Choice: How Students Choose Universities and Colleges. Brighton: Institute for Employment Studies. 
47. Tapp, A., Hicks, K., \& Stone, M. (2004). Direct and database marketing and customer relationship management in recruiting students for higher education. International Journal of Nonprofit and Voluntary Sector Marketing, 9(4), 335-345.

48. Wagner, K., \& Fard, P. Y. (2009). Factors Influencing Malaysian Students 'Intention to Study at a Higher Educational Institution. In E-Leader Kuala Lumpur, 2009 (pp. 1-12).

49. Webb, M. S. (1993). Variables Influencing Graduate Business Students' College Selections. College and University, 68(1), 38-46.

50. Wiese, M., Heerden, C. H. Van, Jordaan, Y., \& North, E. (2009). A marketing perspective on choice factors considered by South African first-year students in selecting a higher education institution. SA Business Review, 13(1), 39-60. Retrieved from https://ro.uow.edu.au/commpapers Part

51. Xiaoping, H. (2002). Soaring Fees at Institutions of Higher Learning Soaring. Chinese Education \& Society ISSN:, 35(1), 21-27. https://doi.org/10.2753/CED1061-1932350121

52. Zain, O. M., \& Nik-Yacob, N. R. (1995). Malaysian university academicians' perceptions of foreign twinning programmes in business and engineering. In Proceedings of Pan-Pacific Conference XII: A business, economics and technological exchange (pp. 194-196). Dunedin and Queenstown, New Zealand: Pan-Pacific Business Association. 